\title{
Loss of imprinting of insulin-like growth factor 2 is associated with increased risk of lymph node metastasis and gastric corpus cancer Yang Lu${ }^{1}$, Ping $\mathrm{Lu}^{2}$, Zhi $\mathrm{Zhu}^{2}$, Huimian $\mathrm{Xu}^{2}$ and Xike Zhu*1
}

Address: ${ }^{1}$ Research Center for Medicine, China Medical University the Shenging Hopital, No. 36, Sanhao ST., Heping District, Shenyang, 110004 , PR China and ${ }^{2}$ Department of Surgical Oncology, China Medial University the First Affiliated Hospital, No. 155, Nanjingbei ST, Heping District, Shenyang, 110001, PR China

Email: Yang Lu - luyang7408@163.com; Ping Lu - lupingllll@yahoo.com; Zhi Zhu - zhuzhiever@163.com;

Huimian Xu - xuhuimian@126.com; Xike Zhu* - zhuxk@sj-hospital.org

* Corresponding author

Published: 9 September 2009

Journal of Experimental \& Clinical Cancer Research 2009, 28:125 doi:I0.1 I86/1756-9966-28-125

This article is available from: http://www.jeccr.com/content/28/I/I25

(C) 2009 Lu et al; licensee BioMed Central Ltd.

This is an Open Access article distributed under the terms of the Creative Commons Attribution License (http://creativecommons.org/licenses/by/2.0), which permits unrestricted use, distribution, and reproduction in any medium, provided the original work is properly cited.
Received: 17 February 2009

Accepted: 9 September 2009

\begin{abstract}
Background: The aim of this study was to determine the clinicopathological features of gastric cancers with loss of imprinting (LOI) of LITI. Insulin-like growth factor 2 (IGF2) and HI 9 in Chinese patients.

Methods: DNA and RNA from tumours were amplified and then digested with Rsal, Apal and Hinfl, and Rsal respectively to determine the LOI status. The demographic and clinicopathological characteristics in LOI positive and LOI negative patients were compared and tested with Statistical analysis.

Results: Of the 89 patients enrolled for analysis, 22, 40 and 35 were heterozygous and thus informative for LITI, IGF2 and HI9 LOI analyses respectively. The positive rate of LITI, IGF2 and $\mathrm{HI} 9 \mathrm{LOI}$ of gastric cancer tissues were $54.6 \%$ (I2/22), $45 \%$ (18/40) and $8.6 \%(3 / 32)$ in Chinese patients. Gastric corpus cancer $(8 / 10,80 \%)$ were more likely to have LOI of IGF2 in tumours than antrum cancers $(10 / 30,33.3 \%)\{$ odds ratio $(\mathrm{OR})=8,95 \%$ confidence intervals $(\mathrm{Cl})=1.425-44.920$, $\mathrm{P}=0.018)\}$. LOI of IGF2 in tumours was also associated with the lymph node metastasis (LNM) $(\mathrm{OR}=4.5,95 \% \mathrm{Cl}=1.084-18.689, \mathrm{p}=0.038)$.
\end{abstract}

Conclusion: IGF2 LOI is present in high frequency in Chinese gastric cancer patients, especially those with gastric corpus cancer.

\section{Background}

Genomic imprinting is an epigenetic modification that leads to the preferential or exclusive expression of a gene from one of the two parental alleles in somatic cells [1]. Abnormal imprinting involved in a number of human diseases, particularly, LOI is one of the most frequent genetic alterations in cancers [2]. LOI can result in either activation or silencing of the normally silent or expressed allele of a growth promoting gene or a growth inhibitory gene, respectively. Research suggests that disruption of imprinting mechanisms may play a critical role in the development of cancer [3]. The cluster of imprinted genes on human chromosome $11 \mathrm{p} 15.5$ comprises two imprinted domains: the IGF2-H19 domain and the KCNQ1 domain [4]. H19 and IGF2 genes are imprinted genes and expressed differently depending on whether they are carried by a chromosome of maternal or paternal origin [5]; normally IGF2 expression is coordinately regu- 
lated with the maternally expressed $\mathrm{H} 19$ gene that produces a noncoding RNA. But in bladder cancer, paternal hypomethylation leads to biallelic H19 expression [6], whereas in Wilms'tumor, maternal hypermethylation and biallelic IGF2 expression are common $[7,8]$. The level of H19 RNAs in Wilms'tumor is also found to inversely correlate with levels of IGF2 mRNA [9], H19 RNAs were found in polysomes, indicative of $\mathrm{H} 19$ translation and/or potential transregulation of IGF2 translation. The upstream promoter region of $\mathrm{H} 19$ has the imprintingcontrol region (ICR) or CTCF binding sites, where the methylation status of this region is critical to the regulation of imprinting of the H19/IGF2 locus located in chromosome 11p15 [10]. LOI of IGF2 is coupled to abnormal H19 methylation in the Wilms tumor case [11]. There may also be an independent mechanism for regulating IGF2 in Beckwith-Wiedemann syndrome (BWS) patients [12]. IGF2 encodes a potent mitogenic growth factor that is active in early development and plays an important role in embryonic and fetal growth [13]. Increased expression of IGF2 is a common feature of both pediatric and adult malignancies since IGF2 binds to the IGF1 receptor to initiate intracellular signaling cascades that lead to cell proliferation [14]. IGF2 stimulates cell proliferation and development in normal human growth. Study showed the overexpressed IGF2 gene is a growth factor for tumors mediated through both the paracrine and autocrine pathways in human cancers. The IGF2 gene may thus play an important role in lymph vessel permeation especially in expanding-type gastric cancers [15]. LOI of IGF2 gene is an important cause of biallelic expression of IGF2 and has been reported in many different types of tumors including osteosarcoma [16], lung adenocarcinomas [17], head and neck squamous cell adenocarcinomas [18], Wilms'tumor [7], prostate cancer [19], and colorectal carcinomas [20]. Studying mice with Apc-Min/+ model of human familial adenomatouspolyposis showed excessive expression of IGF2 resulted increase in the number and the diameter of colon adenoma and increased susceptibility to colon carcinoma [21]. Moreover LOI of IGF2 might provide a marker for identifying an important subset of the population with cancer or at risk of developing cancer [22]. Normally the KvDMR1 in intron 10 of KCNQ1 unmethylated paternally promote LIT1/KCNQ1OT1 expressed paternally antisense RNA [23]. The human LIT1 transcription unit lies within the 11p15.5 imprinted gene cluster and functions as non-coding RNA [24]. Aberrations of LIT1 expression, such as those caused by LOI, involving aberrant hypomethylation and activation of the normally silent maternal allele and LOI IGF2 have been observed in Beckwith-Wiedemann syndrome (BWS) and colorectal cancer $[23,25]$. In addition, loss of maternal-specific methylation at the LIT1 locus in BWS and several cancers correlates with abnormal imprinting status of CDKN1C [26]. Soejima et al. have recently shown that loss of CpG and histone $\mathrm{H} 3$ methylation at a differentially methylated region (DMR)-LIT1 leads to a reduction of CDKN1C expression in esophageal cancer [27]. LOI of IGF2 in gastric tumour tissue except from Taiwan in Chinese and in Japanese patients $[15,28]$ and the clinicopathological features of gastric cancers with LOI of has been reported rarely. In this study LIT1, IGF2 and H19 imprinting status in gastric cancer (GC) which is the second most common cause of cancer-related death in the world was investigated and whether LOI of LIT1, IGF2 and H19 are associated with clinicopathological features was evaluated. The study showed LOI of IGF2 is associated with gastric corpus and LNM in gastric cancer tissues, suggesting that IGF2 plays an important role in gastric carcinogenesis.

\section{Methods}

\section{Tissues and information collection}

The panel of gastric tissues consisted of paired fresh normal adjacent-tumorous and tumorous specimens from 89 GC patients during surgery before any other treatment in the Department of oncology, China Medical University affiliated the first Hospital from March 2007 to February 2008. Written informed consents were obtained from all patients. Demographic and clinicopathologic information were collected from each patient. Tumour location was classified as gastric antrum, gastric corpus, gastric cardia cancer. The tissues were frozen immediately in an $80^{\circ} \mathrm{C}$ freezer until use.

\section{Nucleic acid preparation}

After homogenizing the frozen tissues, genomic DNA was extracted using standard procedures with phenol/chloroform and precipitated with ethanol. RNA was extracted from grounded tissues using guanidinium isothiocyanatephenol solution (RNAzol B, Biotecx Laboratories. Inc., Houston, TX, USA) following the manufacturer's instructions. RNA was treated with Rnase-free DNaseI to eliminate DNA contamination (BRL, Baltimore, MD, USA) and stored at $-80^{\circ} \mathrm{C}$ until use.

\section{Analysis of informative LITI, IGF2 and HI9 cases}

Firstly, analyses were performed from DNA of normal tissues to determine informative cases. Heterozygosity in the LIT1, IGF2 and H19 gene was determined by the presence or absence of RsaI, ApaI and Hinfl, and RsaI sites respectively. Informative genomic heterozygotes for the LIT1, IGF2 and H19 were studied as follows. The polymorphic region of LIT1, IGF2 and H19 were amplified with the primers $[25,18]$ The PCR reaction was conducted in $1 \times$ PCR buffer with $1 \mu \mathrm{m}$ primers, $200 \mu \mathrm{m}$ dNTP, 2.5 units Taq DNA polymerase (Perkin-Elmer, Foster City, CA, USA) and 200 ng genomic DNA. Conditions for amplification were $94^{\circ} \mathrm{C}$ for $2 \mathrm{~min}$ followed by 30 cycles at $94^{\circ} \mathrm{C}$ for $30 \mathrm{sec}, 54 \mathrm{c}, 56^{\circ} \mathrm{C}$ and $58^{\circ} \mathrm{C}$ (for the LIT1, IGF2 and $\mathrm{H} 19$ respectively) for $1 \mathrm{~min}$, and $72^{\circ} \mathrm{C}$ for $1 \mathrm{~min}$. A final 
step was $72^{\circ} \mathrm{C}$ for $5 \mathrm{~min}$. The PCR products were subject to RsaI, ApaI and Hinfl and RsaI (New England Biolabs, Beverly, Mass, USA) enzyme digestion at $37^{\circ} \mathrm{C}$ overnight, run through $12 \%$ acrylamide gel and stained with ethidium bromide respectively. The expected size of the PCR fragment of the LIT1 gene is $410 \mathrm{bp}$. Informative heterozygous cases exhibit three bands of 188, 222 and $410 \mathrm{bp}$. For IGF2 Primers P1 and P3 were also used to get a $1.4 \mathrm{~kb}$ DNA fragment that was used as a size control for the RTPCR product. PCR conditions were the same except for a 1.5-min annealing step at $60^{\circ} \mathrm{C} \mathrm{C}$ with primers $\mathrm{P} 1$ and $\mathrm{P} 3$. The PCR products for IGF2 resulted in a $292 \mathrm{bp}$ band with primers $\mathrm{P} 2$ and $\mathrm{P} 3$. Informative cases are those in which one allele had an ApaI restriction site (256 bp) and the other had an Hinfl restriction site (231 bp). The resultant 655 bp PCR product of $\mathrm{H} 19$ yielded additional 487 bp and $168 \mathrm{bp}$ bands in heterozygotes.

\section{Analysis of LOI of LITI, IGF2 and HI9}

RT-PCR at LIT1, IGF2 and H19 were further analysed for possible allele-specific expression. One microgram total RNA from heterozygous normal and tumor samples was reverse transcribed for the first strand cDNA using the AMV-RT-PCR system (Sangon, Shanghai, China) in a 20 $\mu \mathrm{l}$ reaction. This reaction mixture was added to $80 \mu \mathrm{l}$ of $100 \mu \mathrm{M} \mathrm{dNTP}$ and $2 \mathrm{mM} \mathrm{MgCl} 2,10 \%$ glycerol and 2.5 units Taq polymerase in $1 \times$ PCR buffer. Amplification conditions were carried out as described above. For negative PCR controls, the same primers and reaction conditions with RNA, minus the reverse transcription step were performed. After RsaI digestion of RT-PCR products, informative cases of LIT1 with LOI show biallelic expression of both the 222 and $410 \mathrm{bp}$, while without LOI, showing 222 or 410 band. For IGF2, the RT-PCR product was analysed on $1.5 \%$ agarose gel to verify the $1.12 \mathrm{~kb}$ bands, which were smaller than those observed in DNA analysis $(1.4 \mathrm{~kb})$ with the inclusion of $280 \mathrm{bp}$ intron. Nested PCR wascontinued with the primer P2 as P3 from this 1.12-kb RT-PCR product, resulting in a 292-bp band. After digesting the 292-bp cDNA product from the above RT-PCR reaction with ApaI and HinfI, the presence of 256-bp and 231-bp fragments in a tumor sample indicated biallelic expression. The presence of either the 256 bp or 231 bp band was considered as retention of imprinting. RT-PCR products of $\mathrm{H} 19$ resulted in an obvious 575 bp band from cDNA compared to the control of $655 \mathrm{bp}$ fragment from genomic DNA which includes $80 \mathrm{bp}$ intron. Constitutive imprinting yielded either a single 575-bp band or 407- and 168-bp bands, LOI resulting in 575-bp, 407- and 168-bp fragments after RsaI digestion. The threshold for scoring LOI was defined as a ratio of less than 3-fold difference in expression between two alleles [29].

\section{Statistical analysis}

The prevalence of LOI in patients with gastric cancer was described as a proportion. The demographic and clinicopathological characteristics in LOI positive and LOI negative patients were compared and tested using the ChiSquare test. Logistic regression analyses were used to compute the odds ratios (ORs) and 95\% confidence interval (CI). Independent sample t-test was used to compare the mean age differences between LOI-positive and -negative patients. All statistical analyses were performed with statistical software with SPSS version 13.0 for windows (SPSS, Inc., Chicago IL). All p-values were two-tailed with 0.05 as statistical significance.

\section{Results \\ Loss of imprinting at LITI, IGF2 and HI9 in gastric cancer tissues}

We examined the status of genomic imprinting of the LIT1, IGF2 and H19 genes in 89 gastric cancers by PCRrestriction fragment length polymorphism (RFLP) analysis (Fig. 1, Fig. 2, Fig. 3). Of the 89 tumours analysed, 22, 40 and 35 cases were heterozygous and thus informative for LIT1, IGF2 and H19 LOI analyses respectively as shown in Table 1. LIT1 LOI was observed in 12 of the 22 (54.6\%) informative cases, and its LOI was observed in tumor tissues except only one (4.6\%) LIT1 LOI observed in the adjacent normal tissues. IGF2 LOI was observed in 18 of the $40(45 \%)$ informative cases, and all the cases showed LOI in the adjacent normal tissues. In five cases LOI were observed in the normal tissues, but not in the cancer ones. Only one informative case showed LOI for both LOI LIT1 and IGF2. We observed only 3 LOI H19 of the $32(8.6 \%)$ informative tumors cases, and two cases showed LOI in cancer tissues. In one case, LOI was observed in the normal tissue, but not in the cancerous tissue.

Table I: Summary of allele-specific expression in 89 gastric cancers

\begin{tabular}{lllll}
\hline Gene & Informative(n) & Imprint & LOI & Incidence of LOI in tumor \\
\hline LIT & 22 & 10 & 12 & $12 / 22(54.6 \%)$ \\
\hline IGF2 & 40 & 22 & 18 & $18 / 40(45 \%)$ \\
\hline HI9 & 35 & 32 & 3 & $3 / 32(8.6 \%)$ \\
\hline
\end{tabular}




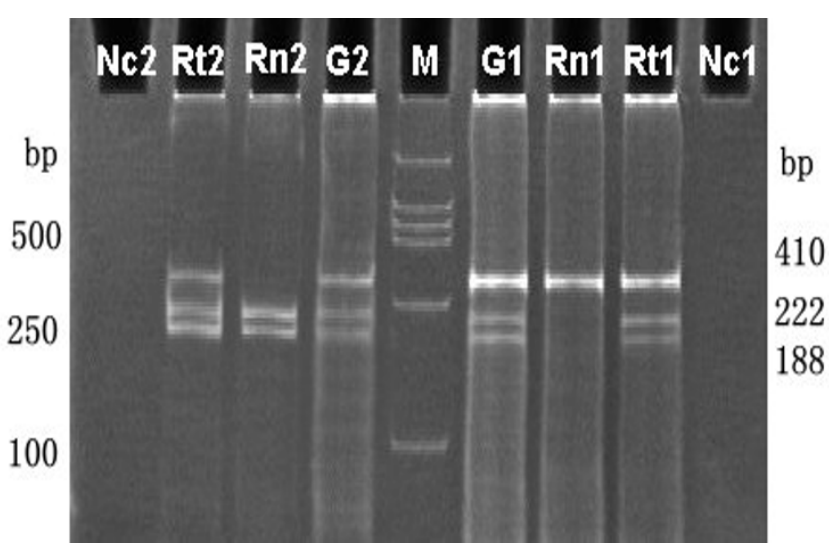

Figure I

Imprinting analysis of LITI in gastric cancer. Rsal digestion of a 410 bp DNA PCR product (GI, G2) yielded bands of 222 and 188 bp indicating heterozygous specimens. Rsal digestion of RT-PCR amplification (RnI, Rn2) showed only one allele expression in both normal tissues indicating maintenance of constitutional imprinting. Rtl, Rt2 displayed three bands in tumor specimens indicating loss of imprinting in contrast to their matching normal tissues (RnI, Rn2). M, marker DL2000. Ncl, Nc2 represented RT-PCR without reverse transcriptase.

\section{Demographic analysis}

The demographic characteristics of patients with or without LOI of LIT1, IGF2 and H19 were shown in Table 2. There were no differences in the mean age, sex ratio, diabetes mellitus(DM), cigarette smoking, alcohol consumption, and family history of GC between the LIT1, IGF2 and H19 LOI(+) versus (-) respectively.

\section{Clinicopathological features according to LOI LITI, IGF2 and $\mathrm{HI} 9$ status and factors associated with positive LOI IGF2}

Of the 40 informative IGF2 tumour samples, 30 tumours were located at the antrum and 10 tumours were located at the gastric corpus. Gastric corpus cancer $(8 / 10,80 \%)$ were more likely to have LOI of IGF2 in tumours than antrum cancers $(10 / 30,33.3 \%)(p=0.028)$ and the positive rate of LOI IGF2 was significantly higher in patients with lymph node metastasis than in those without (69.2\% versus $33.3 \%, p=0.033$ ) as shown in Table 3 . There were no differences in the histological differentiation,, hepatic and peritoneal metastasis, lymphatic or venous invasion, tumour size, stage, Borrmann type and TNM between the LIT1, IGF2 and H19 LOI(+) versus (-) respectively. And there were no differences in the tumor location and lymph node metastasis between the LIT1 and H19 LOI (+) versus(-) respectively. The LOI positive rate of the LIT1, IGF2 and H19 was higher in patients with advanced tumour stage than with early stage, but the difference was not statistically significant $(p=1.000)$.

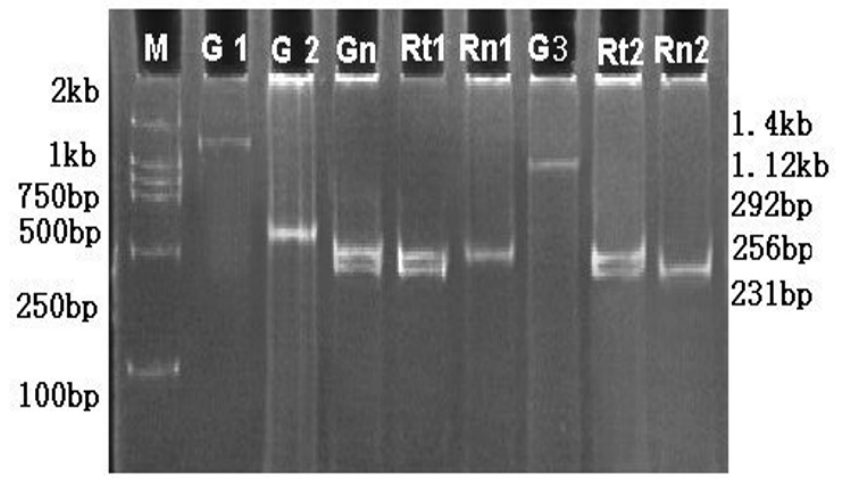

Figure 2

Imprinting analysis of IGF2 in gastric cancer. DNA (GI) and RT-PCR (G3) amplification using primers PI and P3 and DNA amplification by PCR with primers P2 and P3 (G2) represented I.4 kb, I.I2 kb and 292 bp respectively (see details in methods section). GI, G2 and G3 are PCR products of the same normal tissue. Apal- and Hinfl-digested normal tissue DNA PCR (Gn) from primers P2 and P3 displayed two bands of 256 and 23 I bp indicating heterozygosity. The digested nested PCR product from primers $\mathrm{P} 2$ and $\mathrm{P} 3$ using the I.I $2 \mathrm{~kb}$ RT-PCR product as a template showed monoallelic expression of IGF2 in normal $(\mathrm{RnI}, \mathrm{Rn} 2)$ and biallelic expression in tumor (Rtl, Rt2) tissues.

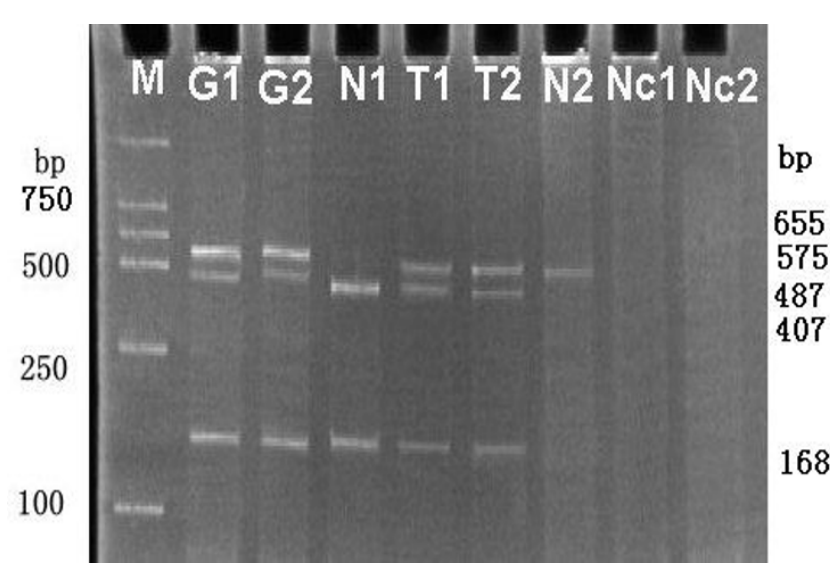

\section{Figure 3}

Imprinting analysis of $\mathrm{HI} 9$ in gastric cancer. $\mathrm{H} / 9$ heterozygosity showed 655 bp DNA PCR product yielded bands of 487 and 168 bp by Rsal digestion (GI, G2). Normal tissues (NI, N2) showed only one allele expression indicating maintenance of normal imprinting (displayed 407 and 168 bp, 575 bp respectively by Rsal digestion RT-PCR products). TI, T2 displayed both three bands (575, 407 and 168 bp respectively) in tumor tissues indicating loss of imprinting in contrast to their matching normal tissues (NI, N2). M, marker DL2000. Ncl, Nc2 represented RT-PCR without reverse transcriptase. 
Table 2: Demographic data of patients with and without LITI, AIGF2 and HI9 LOI

\begin{tabular}{|c|c|c|c|c|c|c|c|c|c|}
\hline & $\begin{array}{l}\text { LITI } \\
\text { LOI (+) } \\
N=12\end{array}$ & $\begin{array}{l}\text { LITI } \\
\text { LOI (--) } \\
N=10\end{array}$ & P-value & $\begin{array}{l}\text { IGF2 } \\
\text { LOI (+) } \\
N=18\end{array}$ & $\begin{array}{l}\text { IGF2 } \\
\text { LOI (--) } \\
N=22\end{array}$ & P-value & $\begin{array}{l}\text { HI9 } \\
\text { LOI(+) } \\
N=3\end{array}$ & $\begin{array}{l}\text { HI9 } \\
\text { LOI (--) } \\
N=32\end{array}$ & P-value \\
\hline Gender & & & 1.000 & & & .749 & & & .708 \\
\hline Male & $9(75 \%)$ & $8(80 \%)$ & & 14 (77.8\%) & $15(68.2 \%)$ & & $3(100 \%)$ & 23 (71.9\%) & \\
\hline Female & $3(25 \%)$ & $2(20 \%)$ & & 4 (22.2\%) & 7 (31.8\%) & & 0 & $9(28.1 \%)$ & \\
\hline Mean age, yr (SD) & $64.5(12.4)$ & $61.3(13.9)$ & 0.574 & $58.6(12.4)$ & $62.7(14.0)$ & .344 & $68.3(13.4)$ & $59.7(13.8)$ & .306 \\
\hline Family history of GC & $4(33.3 \%)$ & 0 & 0.096 & 0 & $4(18.2 \%)$ & .168 & 0 & $4(12.5 \%)$ & 1.000 \\
\hline DM & 0 & $\mathrm{I}(10 \%)$ & 0.455 & $2(11.1 \%)$ & 0 & .196 & 0 & $2(6.25 \%)$ & 1.000 \\
\hline Cigarette smoking & $10(83.3 \%)$ & $7(70 \%)$ & 0.816 & $13(72.2 \%)$ & $13(59.1 \%)$ & .386 & $2(66.7 \%)$ & $22(68.8 \%)$ & 1.000 \\
\hline Alcohol consumption(>10 g/day) & $4(33.3 \%)$ & $3(30 \%)$ & 1.000 & $6(33.3 \%)$ & $5(22.7 \%)$ & .695 & $2(66.7 \%)$ & $9(28.1 \%)$ & .227 \\
\hline
\end{tabular}

LOI: loss of imprinting; SD: standard deviation; GC: gastric cancer; DM: diabetes mellitus

Tumours with LOI of IGF2 are associated with increased risk $(\mathrm{OR}=8,95 \% \mathrm{CI}=1.425-44.920, \mathrm{p}=0.018)$ of the gastric corpus cancer versus those without LOI and the increased risk of the lymph node metastasis $(\mathrm{OR}=4.5$, $95 \% \mathrm{CI}=1.084-18.689, \mathrm{p}=0.038)$ as shown in Table 4 .

\section{Discussion}

The cluster of imprinted genes on human chromosome $11 \mathrm{p} 15.5$ consists of two domains: IGF2-H19 domain and the KCNQ1 domain [4]. LOI of IGF2 has been observed in $10 \%$ of the lymphocytes from normal individuals [30]. In normal human brain, biallelic expression of IGF2 and/ or $\mathrm{H} 19$ is found despite differential methylation and CTCF binding [31]. In this study, we have shown that LOI of the LIT1, IGF2 and H19 are present in 54.6\%, 45\% and $8.6 \%$ of gastric cancer tissues in Chinese patients respectively. This is the first study to detect on the LOI of LIT1, IGF2 and H19 in gastric cancer in China-Mainland patients and LOI of IGF2 positive correlation with gastric corpus tumour $(\mathrm{OR}=8,95 \% \mathrm{CI}=1.425-44.920, \mathrm{p}=$ $0.018)$ and lymph node metastasis $(\mathrm{OR}=4.5,95 \% \mathrm{CI}=$ 1.084-18.689, $\mathrm{p}=0.038$ ).

The frequency of IGF2 LOI (+) gastric cancers (45\%, 18/ $40)$ is slightly higher than that reported from Taiwan $(34.5 \%, 10 / 29)$ [28]. High frequency of IGF2 LOI was observed in tumor and adjacent normal tissues and Igf2 LOI with Apc+/Min mice showed a shift toward less differentiation and an increase in tumor initiation indicating that IGF2 LOI occur at an early stage in cancer development [32]. Although the mechanisms underlying IGF2 LOI in human cancer remains unknown, it is likely to directly or indirectly involve the H19 ICR. We used the allele-specific restriction enzyme digestion technique to identify LOI status, similar to that reported previously [22]. Some papers have explained the mechanisms in the tumourigenesis of gastric carcinogenesis [33]. A variety of epigenetic alterations in human cancers include global DNA hypomethylation, gene hypomethylation and promoter hypermethylation, and IGF2 LOI. The mechanisms for LOI are hypermethylation or hypomethylation of a DMR upstream of the H19 gene, allowing activation of the normally silent maternal allele of IGF2. LOI may precede the development of cancer and may thus serve as a common marker for risk, but also as a model for understanding the developmental mechanism for normal imprinting. Therefore, it is possible that IGF2 LOI play a role in the tumourigenesis through epigenetic modification of DMR. Positive correlations were identified between elevated IGF2 expression and hypermethylation of CTCF binding sites at the H19 proximal imprint center in ovarian cancer [34]. H19 may be a tumor suppressor gene involved in head and neck carcinogenesis [35]. Epigenetic alterations of $\mathrm{H} 19$ or LIT1, which encode untranslated RNAs on $11 \mathrm{p} 15$, are strongly associated with cancer risk or specific birth defects in BWS [36].

We found that gastric corpus cancer is associated with higher IGF2 positive LOI rate, while Liou et al [37] found that proximal colon cancer is independently associated with higher positive LOI rate, consistent with a recent report from Japan [38]. However, larger population are needed to screen whether IGF2 LOI is involved in which pathways of gastric carcinogenesis. LOI of LIT1 involves aberrant hypomethylation and activation of the normally silent maternal allele. Our data suggest that LIT1 LOI may 
Table 3: Association of clinicopathological features with LITI, AIGF2 and HI9 LOI

\begin{tabular}{|c|c|c|c|c|c|c|c|c|c|}
\hline & $\begin{array}{l}\text { LIT I } \\
\text { LOI (+) } \\
N=12\end{array}$ & $\begin{array}{l}\text { LITI } \\
\text { LOI (--) } \\
N=10\end{array}$ & P-value & $\begin{array}{l}\text { IGF2 } \\
\text { LOI (+) } \\
N=18\end{array}$ & $\begin{array}{l}\text { IGF2 } \\
\text { LOI (--) } \\
N=22\end{array}$ & P-value & $\begin{array}{l}\text { HI9 } \\
\text { LOI(+) } \\
N=3\end{array}$ & $\begin{array}{l}\text { HI9 } \\
\text { LOI (--) } \\
\mathrm{N}=32\end{array}$ & P-value \\
\hline Tumor location & & & 1.000 & & & .028 & & & .633 \\
\hline antrum, & $10(83.3 \%)$ & $8(80 \%)$ & & $10(55.6 \%)$ & $20(90.9 \%)$ & & $3(100 \%)$ & $22(68.8 \%)$ & \\
\hline gastric corpus, & $2(16.7 \%)$ & $2(10 \%)$ & & $8(44.4 \%)$ & $2(9.1 \%)$ & & 0 & $10(31.2 \%)$ & \\
\hline gastric cardia & 0 & 0 & & 0 & 0 & & 0 & 0 & \\
\hline $\begin{array}{l}\text { Histological differentiation } \\
\text { (well, mod/poor, muc) }\end{array}$ & $5 / 7$ & $4 / 6$ & 1.000 & $9 / 9$ & $10 / 12$ & .775 & $\mathrm{I} / 2$ & $15 / 17$ & 1.000 \\
\hline Lymph node metastasis & $5(4 \mid .7 \%)$ & $4(40 \%)$ & 1.000 & $9(50 \%)$ & $4(18.2 \%)$ & .033 & I (33.3\%) & $12(37.5 \%)$ & 1.000 \\
\hline Hepatic and peritoneal metastasis & I (8.3\%) & 0 & 1.000 & $\mathrm{I}(5.6 \%)$ & I (4.6\%) & 1.000 & 0 & $2(6.25 \%)$ & 1.000 \\
\hline Lymphatic invasion & $4(33.3 \%)$ & $\mathrm{I}(10 \%)$ & .323 & $4(22.2 \%)$ & $4(18.2 \%)$ & 1.000 & 0 & $8(25 \%)$ & .789 \\
\hline Venous invasion & I (8.3\%) & 0 & 1.000 & I (5.6\%) & I (4.6\%) & 1.000 & 0 & $2(6.25 \%)$ & 1.000 \\
\hline Tumour Size & & & .746 & & & .332 & & & .423 \\
\hline$<2 \mathrm{~cm}$ & 0 & 0 & & $3(16.7 \%)$ & $6(27.3 \%)$ & & 0 & $6(18.8 \%)$ & \\
\hline $2--5 \mathrm{~cm}$ & $8(66.7 \%)$ & $6(60 \%)$ & & 7 (38.9\%) & II (50\%) & & I (33.3\%) & $16(50 \%)$ & \\
\hline$>5 \mathrm{~cm}$ & $4(33.3 \%)$ & $4(40 \%)$ & & $8(44.4 \%)$ & $5(22.7 \%)$ & & $2(66.7 \%)$ & 10 (31.3\%) & \\
\hline TNM & & & .369 & & & .525 & & & .208 \\
\hline $\mathrm{T}+\mathrm{N}+\mathrm{M}=<3$ & 7 (58.3\%) & $3(30 \%)$ & & $8(44.4 \%)$ & $12(54.6 \%)$ & & 0 & $18(56.3 \%)$ & \\
\hline $\mathrm{T}+\mathrm{N}+\mathrm{M}>=4$ & 5 (4I.7\%) & $7(70 \%)$ & & $10(55.6 \%)$ & $10(45.4 \%)$ & & $3(100 \%)$ & 14 (43.7\%) & \\
\hline Stage & & & 1.000 & & & 1.000 & & & 1.000 \\
\hline early & I (8.3\%) & 0 & & 0 & I (4.6\%) & & 0 & I (3.I\%) & \\
\hline advanced & II (91.7\%) & $10(100 \%)$ & & $18(100 \%)$ & 21 (95.4\%) & & $3(100 \%)$ & 31 (96.9\%) & \\
\hline Borrmann type & & & .620 & & & .337 & & & .753 \\
\hline I & I (9.1\%) & 0 & & 0 & $2(9.5 \%)$ & & 0 & $2(6.5 \%)$ & \\
\hline II & 0 & 0 & & 0 & 0 & & 0 & 0 & \\
\hline III & 9 (81.8\%) & $9(90 \%)$ & & 16 (88.9\%) & I8 (85.7\%) & & $3(100 \%)$ & 26 (83.9\%) & \\
\hline IV & I (9.1\%) & $\mathrm{I}(10 \%)$ & & $2(11.1 \%)$ & I (4.8\%) & & 0 & $3(9.7 \%)$ & \\
\hline
\end{tabular}


Table 4: Odds ratio for gastric corpus cancer and lymph node metastasis of the LOI IGF-2

\begin{tabular}{lll}
\hline Variable & Patients with gastric corpus cancer & OR for gastric corpus cancer (95\% Cl) \\
\hline IGF2 LOI $(+)$ & $44.4 \%(8 / 18)$ & $8(1.425-44.920, p=.018)$ \\
\hline Normal imprinting & $9.1 \%(2 / 22)$ & 1 \\
\hline & Lymph node metastasis & OR for lymph node metastasis $(95 \% \mathrm{Cl})$ \\
\hline IGF2 LOI +$)$ & $50 \%(9 / 18)$ & $4.5(1.084-18.689, \mathrm{p}=.038)$ \\
\hline Normal imprinting & $18.2 \%(4 / 22)$ & 1 \\
\hline
\end{tabular}

OR: odds ratio; Cl: confidence interval; IGF-2: insulin growth factor 2; LOI: loss of imprinting

be associated with gastric cancer tumorigenesis. Histone modifications and DNA methylation are important for the regulation of LIT1 expression to form active or repressive chromatin structure [27]. LIT1 is a non-coding RNA, like Xist, Tsix and Air, LIT1 RNA plays a critical role in the bidirectional spreading of inactive chromatin structures [39], silencing imprinting genes [40] and formating of the imprinting center (IC) to coordinate imprinting in the 11p15.5 region. Timing of LIT1 RNA expression is vital for the proper initiation of imprinting genes [41,42]. Premature termination of the LIT1 transcript leads to LOI in the proximal region indicating full-length Lit1 RNA is necessary for maintaining the imprinting status [43]. Mouse Lit1 RNA plays a critical role in silencing at the IC of the imprinted gene cluster and the transcript length of Lit1 RNA is important for the degree of silencing [44].

And we found patients with LOI of IGF2 in their tumour had higher increased risk of the lymph node metastasis than those without $(\mathrm{OR}=4.5,95 \% \mathrm{CI}=1.084-18.689, \mathrm{p}=$ 0.038 ). Recently our study found metastatic lymph node ratio is a useful independent prognostic factor and may obviate possible confounding factors that are related to stage migration, and should be considered as an important component in the lymph node ategory. Lymph node ratio category has advantages in providing a more precise prognostic value than the $\mathrm{pN}$ category (5th edition, UICC). We recommend that classification of nodal status be established by a combination of both the metastatic nodes number and ratio, which would be the best category to provide both rational lymph node dissection and the foundation for adjunctive therapy and predict the prognosis [45]. Ohashi et al reported conventional pathological factors, such as tumor size, depth of submucosal invasion, and lymphatic invasion, have a significant influence on lymph node metastasis in submucosal invasive gastric cancer [46]. Li et al showed depth of invasion, lymph node metastasis, hepatic and peritoneal metastasis and surgical curability were significant factors affecting survival of the gastric carcinoma patients [47]. But we failed to find such an association. Liu et al found transversal and skipping metastases of sentinel lymph nodes (SLN) are notable and therefore rational lymphadenectomy should be performed in primary gastric cancer [48]. Some research demonstrated lymph node metastasis were independent prognostic factors in human gastric carcinoma [49]. And high expression of mitotic centromereassociated kinesin (MCAK) and tripartite motif-containing 29 (TRIM29) are predictors for lymph node metastasis $[50,51]$. It might be more appropriate that identifying patients at high risk of lymph node metastasis who should be offered gastrectomy rather than endoscopic mucosal resection, because patients with lymph node metastasis are more likely to express IGF2 LOI than those without. Our result was consistent with other studies that LOI of IGF2 is also important in the carcinogenesis $[15,28]$.

\section{Conclusion}

In all, high frequency of IGF2 LOI is present in patients with gastric cancer in the northeast of China. The association of IGF2 LOI with lymph node metastasis may contribute to the development and progression of gastric cancer.

\section{Abbreviations}

GC: gastric cancer; LNM: lymph node metastasis; LOI: loss of imprinting; IGF2: Insulin-like growth factor 2; DM: diabetes mellitus; SD: standard deviation; CI: confidence interval; OD: odds ratio; BWS: Beckwith-Wiedemann syndrome; DMR: differentially methylated region; RFLP: restriction fragment length polymorphism; ICR: imprinting-control region.

\section{Competing interests}

This paper has not been published elsewhere in whole or in part. All authors have read and approved the content, and agree to submit for consideration for publication in the journal. 'The authors declare that they have no ethical, financial or legal competing interests in this article. 


\section{Authors' contributions}

YL carried out nucleic acid preparation, PCR, RT-PCR and PCR-RFLP analysis, performed the statistical analysis. PL, $\mathrm{HX}$ and $\mathrm{ZZ}$ participated in tissues, information collection and PCR- RFLP analysis. ZZ, HX and XZ participated in statistical analysis and helped to draft the manuscript. All authors read and approved the final manuscript.

\section{Acknowledgements}

This work was financially supported by National Natural Science Foundation of China (contract No. 30470963) and by Shengjing Free Research Foundation from The Shengjing Hospital of China Medical University.

\section{References}

I. Feinberg AP: A genetic approach to cancer epigenetics. Cold Spring Harb Symp Quant Biol 2005, 70:335-34I.

2. Murrell A: Genomic Imprinting and Cancer: From Primordial Germ Cells to Somatic Cells. Scientific World J 2006, 6:1888-1910.

3. Walter J, Paulsen M: Imprinting and disease. Semin Cell Dev Biol 2003, I 4:101-110

4. Delaval K, Wagschal A, Feil R: Epigenetic deregulation of imprinting in congenital diseases of aberrant growth. BioEssays 2006, 28:453-459.

5. Zemel S, Bartolomei MS, Tilghman SM: Physical linkage of two mammalian imprinted genes, $\mathrm{HI} 9$ and insulin-like growth factor 2. Nat Genet 1992, 2:61-65.

6. Takai D, Gonzales FA, Tsai YC, Thayer MJ, Jones PA: Large scale mapping of methylcytosines in CTCF-binding sites in the human $\mathrm{HI} 9$ promoter and aberrant hypomethylation in human bladder cancer. Hum Mol Genet 200I, 10:2619-2626.

7. Ravenel JD, Broman KW, PerIman EJ, Niemitz EL, Jayawardena TM, Bell DW, Haber DA, Uejima H, Feinberg AP: Loss of imprinting of insulinlike growth factor-2 (IGF2) gene in distinguishing specific biologic subtypes of Wilms tumor. J Natl Cancer Inst 200 I, 93:1698-1703.

8. Cui H, Niemitz EL, Ravenel JD, Onyango P, Brandenburg SA, Lobanenkov VV, Feinberg AP: Loss of imprinting of insulin-like growth factor-2 in Wilms'tumor commonly involves altered methylation but not mutations of CTCF or its binding site. Cancer Res 200 I, 61:4947-4950.

9. Li YM, Franklin G, Cui HM, Svensson K, He XB, Adam G, Ohlsson R, Pfeifer S: The HI9 transcript is associated with polysomes and may regulate IGF2 expression in trans. J Biol Chem 1998, 273:28247-28252

10. Feinberg AP: Cancer epigenetics takes center stage. Proc Natl Acad Sci USA 200I, 98:392-394.

II. Steenman MJ, Rainier S, Dobry CJ, Grundy P, Horon IL, Feinberg AP: Loss of imprinting of IGF2 is linked to reduced expression and abnormal methylation of $\mathbf{H I 9}$ in Wilms' tumor. Nat Genet 1994, 7:433-439.

12. Joyce JA, Lam WK, Catchpoole DJ, Jenks P, Reik W, Maher ER, Schofield PN: Imprinting of IGF2 and HI9: lack of reciprocity in sporadic Beckwith-Wiedemann syndrome. Hum Mol Genet 1997, 6:1543-1548.

13. Reik W, Constancia M, Dean W, Davies K, Bowden L, Murrell A, Feil $\mathrm{R}$, Walter J, Kelsey G: Igf2 imprinting in development and disease. Int J Dev Biol 2000, 44:I45-I50.

14. Foulstone E, Prince S, Zaccheo O, Burns JL, Harper J, Jacobs C, Church $D$, Hassan $A B$ : Insulin-like growth factor ligands, receptors, and binding proteins in cancer. J Pathol 2005, 205: I 45-I 53.

15. Shiraishi T, Mori M, Yamagata M, Haraguchi M, Ueo H, Sugimachi K: Expression of insulin-like growth factor 2 mRNA in human gastric cancer. Int J Oncol I998, 13:519-523.

16. Ulaner GA, Vu TH, Li T, Hu JF, Yao XM, Yang Y, Gorlick R, Meyers $P$, Healey J, Ladanyi M, Hoffman AR: Loss of imprinting of IGF2 and $\mathrm{HIO}$ in osteosarcoma is accompanied by reciprocal methylation changes of a CTCFbinding site. Hum Mol Genet 2003, I 2:535-549.

17. Kohda M, Hoshiya H, Katoh M, Tanaka I, Masuda R, Takemura T, Fujiwara M, Oshimura M: Frequent loss of imprinting of IGF2 and MEST in lung adenocarcinoma. Mol Carcinog 200I, 3 I: |84-19|.
18. el-Naggar AK, Lai S, Tucker SA, Clayman GL, Goepfert H, Hong WK, Huff V: Frequent loss of imprinting at the IGF2 and HI 9 genes in head and neck squamous carcinoma. Oncogene 1999 , 1 8:7063-7069.

19. Jarrard DF, Bussemakers MJ, Bova GS, Isaacs WB: Regional loss of imprinting of the insulin-like growth factor 2 gene occurs in human prostate tissues. Clin Cancer Res 1995, I:147|-1478.

20. Cui H, Cruz-Correa M, Giardiello FM, Hutcheon DF, Kafonek DR, Brandenburg S, Wu Y, He X, Powe NR, Feinberg AP: Loss of IGF2 imprinting: a potential marker of colorectal cancer risk. Science 2000, 299:1753-1755.

21. Hassan $A B$, Howell JA: Insulin-like growth factor 2 supply modifies growth of intestinal adenoma in Apc(Min/+) mice. Cancer Res 2000, 60:1070-1076.

22. Cui H, Horon IL, Ohlsson R, Hamilton SR, Feinberg AP: Loss of imprinting in normal tissue of colorectal cancer patients with microsatellite instability. Nat Med 1998, 4:1276-1280.

23. Lee MP, DeBaun MR, Mitsuya K, Galonek HL, Brandenburg S, Oshimura M, Feinberg AP: Loss of imprinting of a paternally expressed transcript, with antisense orientation to KVLQTI, occurs frequently in Beckwith-Wiedemann syndrome and is independent of insulin-like growth factor 2 imprinting. Proc Natl Acad Sci USA 1999, 96:5203-5208.

24. Mitsuya K, Meguro M, Lee MP, Katoh M, Schulz TC, Kugoh H, Yoshida MA, Niikawa N, Feinberg AP, Oshimura M: LITI, an imprinted antisense RNA in the human KvLQTI locus identified by screening for differentially expressed transcripts using monochromosomal hybrids. Hum Mol Genet 1999, 8:1209-1217.

25. Tanaka K, Shiota G, Meguro M, Mitsuya K, Oshimura M, Kawasaki H: Loss of imprinting of long QT intronic transcript $I$ in colorectal cancer. Oncology 200I, 60:268-273.

26. Nakano S, Murakami K, Meguro M, Soejima H, Higashimoto K, Urano T, Kugoh H, Mukai T, Ikeguchi M, Oshimura M: Expression profile of LITI/KCNQ IOTI and epigenetic status at the KvDMRI in colorectal cancers. Cancer Sci 2006, 97: I I47-I I 54.

27. Soejima H, Nakagawachi T, Zhao W, Higashimoto K, Urano T, Matsukura S, Kitajima Y, Takeuchi M, Nakayama M, Oshimura M, Miyazaki $\mathrm{K}$, Joh K, Mukai T: Silencing of imprinted CDKNIC gene expression is associated with loss of $\mathrm{CpG}$ and histone $\mathrm{H3}$ lysine 9 methylation at DMR-LITI in esophageal cancer. Oncogene 2004, 23:4380-4388.

28. Wu MS, Wang HP, Lin CC, Sheu JC, Shun CT, Lee WJ, Lin JT: Loss of imprinting and overexpression of IGF2 gene in gastric adenocarcinoma. Cancer Lett 1997, I 20:9-14.

29. Cruz-Correa M, Cui H, Giardiello FM, Powe NR, Hylind L, Robinson A, Hutcheon DF, Kafonek DR, Brandenburg S, Wu Y, He X, Feinberg AP: Loss of imprinting of insulin growth factor 2 gene: a potential heritable biomarker for colon neoplasia predisposition. Gastroenterology 2004, I 26:964-970.

30. Sakatani T, Wei M, Katoh M, Okita C, Wada D, Mitsuya K, Meguro M, Ikeguchi M, Ito H, Tycko B, Oshimura M: Epigenetic heterogeneity at imprinted loci in normal populations. Biochem Biophys. Res Commun 200I, 283: I I24-I I30.

3I. Ulaner GA, Yang Y, Hu JF, Li T, Vu TH, Hoffman AR: CTCF binding at the insulin-like growth factor-2 (IGF2)/HI9 imprinting control region is insufficient to regulate IGF2/HI9 expression in human tissues. Endocrinology 2003, 144:4420-4426.

32. Sakatani T, Kaneda A, lacobuzio-Donahue CA, Carter MG, de Boom Witzel S, Okano H, Ko MS, Ohlsson R, Longo DL, Feinberg AP: Loss of imprinting of Igf2 alters intestinal maturation and tumorigenesis in mice. Science 2005, 307:1976-1978.

33. Vogiatzi P, Vindigni C, Roviello F, Renieri A, Giordano A: Deciphering the underlying genetic and epigenetic events leading to gastric carcinogenesis. / Cell Physiol 2007, 2 I I:287-295.

34. Lu L, Katsaros D, Wiley A, Rigault de la Longrais IA, Risch HA, Puopolo $\mathrm{M}, \mathrm{Yu} \mathrm{H}$ : The relationship of insulin-like growth factor-2, insulin-like growth factor binding protein-3, and estrogen receptor-alpha expression to disease progression in epithelial ovarian cancer. Clin Cancer Res 2006, I 2:1208-1214.

35. Rainho CA, Kowalski LP, Rogatto SR: Loss of imprinting and loss of heterozygosity on I I P I5.5 in head and neck squamous cell carcinomas. Head Neck 200I, 23:85I-859.

36. DeBaun MR, Niemitz EL, McNeil DE, Brandenburg SA, Lee MP, Feinberg AP: Epigenetic alterations of $\mathrm{HI} 9$ and LITI distinguish patients with Beckwith-Wiedemann syndrome with cancer and birth defects. Am J Hum Genet 2002, 70:604-6II. 
37. Liou JM, Wu MS, Lin JT, Wang HP, Huang SP, Chiu HM, Lee YC, Lin $Y B$, Shun CT, Liang JT: Loss of imprinting of insulin-like growth factor $\mathbf{2}$ is associated with increased risk of proximal colon cancer. Eur J Cancer 2007, 43:1276-I282.

38. Sasaki J, Konishi F, Kawamura YJ, Kai T, Takata O, Tsukamoto T: Clinicopathological characteristics of colorectal cancers with loss of imprinting of insulin-like growth factor 2. Int J Cancer 2006, I 1 9:80-83.

39. Thakur N, Tiwari VK, Thomassin H, Pandey RR, Kanduri M, Göndör A, Grange T, Ohlsson R, Kanduri C: An antisense RNA regulates the bidirectional silencing property of the Kcnq I imprinting control region. Mol Cell Biol 2004, 24:7855-7862.

40. Fitzpatrick GV, Soloway PD, Higgins MJ: Regional loss of imprinting and growth deficiency in mice with a targeted deletion of KvDMRI. Nat Genet 2002, 32:426-43I.

4I. Lewis A, Green K, Dawson C, Redrup L, Huynh KD, Lee JT, Hemberger M, Reik W: Epigenetic dynamics of the Kcnq I imprinted domain in the early embryo. Development 2006, I33:4203-4210.

42. Green K, Lewis A, Dawson C, Dean W, Reinhart B, Chaillet JR, Reik W: A developmental window of opportunity for imprinted gene silencing mediated by DNA methylation and the Kcnql ot I noncoding RNA. Mamm Genome 2007, 18:32-42.

43. Mancini-Dinardo D, Steele SJ, Levorse JM, Ingram RS, Tilghman SM: Elongation of the Kcnqlotl transcript is required for genomic imprinting of the neighboring genes. Genes Dev 2006 20:1268-1282.

44. Kanduri C, Thakur N, Pandey RR: The length of the transcript encoded from the Kcnq lot I antisense promoter determines the degree of silencing. EMBO J 2006, 25:2096-2 106

45. Liu C, Lu P, Lu Y, Xu H, Wang S, Chen J: Clinical implications of metastatic lymph node ratio in gastric cancer. BMC Cancer 2007, 10:200.

46. Ohashi S, Okamura S, Urano F, Maeda M: Clinicopathological variables associated with lymph node metastasis in submucosal invasive gastric cancer. Gastric Cancer 2007, 10:24I-250.

47. Li C, Kim S, Lai JF, Hyung WJ, Choi WH, Choi SH, Noh SH: Advanced gastric carcinoma with signet ring cell histology. Oncology 2007, 72:64-68.

48. Liu CG, Lu P, Lu Y, Jin F, Xu HM, Wang SB, Chen JQ: Distribution of solitary lymph nodes in primary gastric cancer: $A$ retrospective study and clinical implications. World J Gastroenterol 2007, I 3:4776-4780.

49. Kolev $\mathrm{Y}$, Uetake H, lida S, Ishikawa T, Kawano T, Sugihara K: Prognostic significance of VEGF expression in correlation with COX-2, microvessel density, and clinicopathological characteristics in human gastric carcinoma. Ann Surg Oncol 2007, 14:2738-2747.

50. Nakamura $Y$, Tanaka F, Haraguchi N, Mimori K, Matsumoto T, Inoue $\mathrm{H}$, Yanaga $\mathrm{K}$, Mori M: Clinicopathological and biological significance of mitotic centromere-associated kinesin overexpression in human gastric cancer. $\mathrm{Br} /$ Cancer 2007, 97:543-549.

5I. Kosaka Y, Inoue H, Ohmachi T, Yokoe T, Matsumoto T, Mimori K, Tanaka F, Watanabe M, Mori M: Tripartite motif-containing 29 (TRIM29) is a novel marker for lymph node metastasis in gastric cancer. Ann Surg Oncol 2007, 14:2543-2549.
Publish with Biomed Central and every scientist can read your work free of charge

"BioMed Central will be the most significant development for disseminating the results of biomedical research in our lifetime. "

Sir Paul Nurse, Cancer Research UK

Your research papers will be:

- available free of charge to the entire biomedical community

- peer reviewed and published immediately upon acceptance

- cited in PubMed and archived on PubMed Central

- yours - you keep the copyright
BiolMedcentral 